Research article

\title{
TYPING OF INDIGENOUS CAMPYLOBACTER spp. FROM SERBIA BY m-PCR AND RAPD
}

\author{
JOŠIĆ Dragana ${ }^{1}$, PETKOVIĆ Jelena ${ }^{2 *}$, BUNČIĆ Olivera ${ }^{3}$, LEPŠANOVIĆ Zorica ${ }^{4}$, \\ PIVIĆ Radmila ${ }^{1}$, RAŠIĆ Zoran ${ }^{2}$, KATIĆ Vera ${ }^{3}$
}

\begin{abstract}
${ }^{1}$ Institute for Soil Science, Teodora Drajzera 7, 11000 Belgrade, Serbia; ${ }^{2}$ Institute of Veterinary Medicine, Boška Jovića 6, 35000 Jagodina, Serbia; ${ }^{3}$ Faculty of Veterinary Medicine, Bulevar Oslobođenja 18, 11000 Belgrade, Serbia; ${ }^{4}$ Military Medical Academy, Crnotravska 17, 11000 Belgrade, Serbia
\end{abstract}

(Received 15 October 2015; Accepted 06 April 2016)

Campylobacteriosis is an infectious human disease caused by thermophilic Campylobacter species, mainly $C$. jejuni and C. coli. It is the leading cause of human gastroenteritis today with the number of cases surpassing the number of Salmonella poisoning cases. The epidemiology of the agent is not completely clear, but a number of investigations indicate an important role of broiler meat in human infections. The purpose of this study was to investigate the diversity of Campylobacter jejuni strains present in the Republic of Serbia and to determine a fast and reliable system for the confirmation and typing of the isolated strains. Samples taken at slaughterhouses, broiler farms, as well as two human isolates of Campylobacter species have been investigated. Strain identification was performed by multiplex-PCR. Genotyping was performed by Random Amplified Polymorphic DNA (RAPD) with multiple primers. Using several unusual primers and a newly designed one (DJP17), we report on the RAPD types of indigenous Campylobacter species. RAPD profiles showed different levels of discrimination between the isolates, depending on the primer: SPH1 and AG15 were informative only in part and better results were obtained with AP10, AK16 and DJP17.

Key words: broilers, Campylobacter spp., epidemiology, multiplex-PCR, RAPD

\section{INTRODUCTION}

Campylobacter species have been recognised as important pathogens of humans and animals [1,2]. Thermotolerant species as $C$. jejuni and $C$. coli cause gastroenteritis in humans and colonize the intestines of poultry, pigs and cattle. During the past few decades bacteria from this genus became the most common cause of food-borne enteritis in developed and developing countries, surpassing the number of Salmonella enteritis cases [3]. Approximately 9 million cases of campylobacteriosis occur in the EU

\footnotetext{
*Corresponding author: e-mail: jelapet@gmail.com
} 
yearly [4]. These data emphasizes Campylobacter species (especially C.jejuni) as emerging food-borne pathogens along with Norovirus and Listeria monocytogenes [2,5].

The disease usually occurs with symptoms of enteritis. The illness is self-limited, the symptoms cease approximately in a week without treatment. Complications as Guillian-Barr syndrome, arthritis or septicemia in immune-compromised individuals, are possible, but rare.

The epidemiology of Campylobacter spp. is not quite clear yet, but it is known that major reservoirs of the agent are poultry, pigs and cattle [6, 7]. The agent normally occurs in the intestine of those animals, providing no symptoms [8]. Commercial flocks of broilers and laying hens are considered as the main reservoir of the agent in nature [9]. Current epidemiological studies suggest that poultry meat is one of the vehicles for transfer of the infection to humans [10,11].

The isolation of the agent is difficult, time consuming and expensive. Problems may occur if bacterial cells are damaged (isolation can be unsuccessful) and traditional bacteriological isolation techniques are laborious and slow. Nowadays investigators tend to rely more on genetic tools both for detection and typing of Campylobacters [12,13]. Identification of species can be performed by biochemical tests, but the verification of the biochemistry is often needed. This verification is performed by multiplex-PCR (m-PCR) method, using different combinations of primer pairs specific for C. jejuni and C. coli, the main pathogens from the genus [14].

Appropriate typing methods are necessary in order to conduct epidemiological studies. Numerous investigators recommend the use of the RAPD method for Campylobacter typing [12,13]. Møller Nielsen et al. [15] concluded that RAPD and PFGE had a better discriminatory power in Campylobacter species comparing to flaA-RFLP, flaA-DGGE, rybotyping and Penner serotyping. Trajkovska-Dokić et al. [16] compared Penner serotyping and RAPD for typing of $C$. jejuni isolates and concluded that RAPD can be used for this purpose.

The aim of this study was to investigate the diversity of Campylobacter jejuni strains among isolates from poultry farms and slaughterhouses in the Republic of Serbia by employing m-PCR and RAPD methods.

\section{MATERIALS AND METHODS}

\section{Bacterial isolates}

Culture collection used in this study consisted of 55 isolates obtained from a broiler farm and slaughterhouses in the region of Pomoravlje. All isolates were biochemically confirmed as Campylobacter spp. Two human feces isolates were included in the study. Isolates were stored in Tryptic Soy broth (Oxoid, UK) with 20\% of glycerol (Centrohem, Serbia) at $-80^{\circ} \mathrm{C}$. Subset of 30 isolates was used for molecular analysis (Table 1).

Referent strains were Campylobacter jejuni ATCC 33291 (R50) and Campylobacter jejuni ATCC 29428 (R51). 


\section{Detection of Campylobacter species}

The method used for detection of Campylobacter spp. was EN/ISO 10272-1:2006 Microbiology of food and animal feedstuffs - Horizontal method for detection and enumeration of Campylobacter species - Part 1: detection method and the nutrient media used were produced by Oxoid, UK.

\section{DNA extraction}

The isolates were grown on Columbia blood agar (Oxoid, UK) prior to DNA extraction. Colonies were suspended in $200 \mu \mathrm{TE}$ (Tris-EDTA) buffer, heated for 10 min at $95^{\circ} \mathrm{C}$ and rapidly cooled to $-20^{\circ} \mathrm{C}$ for $5 \mathrm{~min}$ for cell lysis, centrifuged at 13000 $\mathrm{rpm}$ for $5 \mathrm{~min}$. Amount of $50 \mu \mathrm{l}$ of supernatant was transferred into $500 \mu \mathrm{l}$ TE buffer and stored on $-20^{\circ} \mathrm{C}$ pending investigation. Supernatant containing DNA $(1 \mu \mathrm{l})$ has been used in each PCR reaction as the template.

\section{Multiplex-PCR}

For identification of C. jejuni and C. coli, m-PCR reaction was carried out according to the protocol described by Denis et al. [14], modified by using only primers for mapA and $c e n \mathrm{E}$ gene.

\section{RAPD}

Amplification was conducted in $25 \mu$ l total volume containing DreamTaqGreen Master Mix (ThermoScientific, Lithuania), $1 \mu$ of DNA template and $0.1 \mu \mathrm{M}$ of primers. The amplification conditions were as described earlier: for the primers OPA8, OPA10 [17], AG15, AF14, BC318, AX16, AK16 [18], SPH1 [19], and AP10 [20]. The amplification condition for the primer DJP17 (GTGCGCATCAGGCCGTA), designed in this study, included initial denaturation at $95^{\circ} \mathrm{C}$ for $5 \mathrm{~min}, 35$ cycles each consisting of 1 min at $94^{\circ} \mathrm{C}, 1 \mathrm{~min}$ at $57^{\circ} \mathrm{C}, 2 \mathrm{~min}$ at $72^{\circ} \mathrm{C}$ and a final extension step of 5 min at $72^{\circ} \mathrm{C}$. All products of amplifications were separated by gel electrophoresis on 1.5\% agarose gel in $0.5 \mathrm{x}$ Tris borate EDTA buffer at $5 \mathrm{~V} / \mathrm{cm}$ and visualized under UV light.

\section{Cluster analysis}

Cluster analysis was performed by unweighted pair group arithmetic average-linkage algorithm (UPGMA) and statistically analyzed by STATISTICA 7 software.

\section{RESULTS}

\section{Biochemical and $m-P C R$ analysis}

Total of 30 out of 55 isolates were confirmed as Campylobacter spp. by biochemical tests (Table 1). Hippurate hydrolysis test revealed that nine of tested isolates were 
C. jejuni, and 20 C. coli. One of the isolates (B6) could not be classified as neither of the species. Results of biochemical testing of human isolates confirmed one of the isolates as $C$. jejuni and one as $C$. coli.

Table 1. Source of Campylobacter spp. isolates and identification and typing results

\begin{tabular}{|c|c|c|c|c|c|}
\hline $\begin{array}{l}\text { Sampling } \\
\text { location }\end{array}$ & $\begin{array}{l}\text { Sample } \\
\text { category }\end{array}$ & Isolate & $\begin{array}{l}\text { Biochemical } \\
\text { tests }\end{array}$ & m-PCR & $\begin{array}{l}\text { RAPD } \\
\text { pattern }\end{array}$ \\
\hline \multirow[t]{11}{*}{ Slaughterhouse A } & \multirow[t]{11}{*}{ Carcass swab } & A1 & C. coli & C. coli & $\mathrm{a}$ \\
\hline & & A2 & C. jejuni & C. coli & a \\
\hline & & A4 & C. coli & C. coli & a \\
\hline & & A43 & C. jejuni & C. jejuni & $\mathrm{b}$ \\
\hline & & A 46 & C. jejuni & C. jejuni & $\mathrm{b}$ \\
\hline & & A53 & C. jejuni & $\begin{array}{l}\text { C. jejuni } \\
\text { and C. coli }\end{array}$ & / \\
\hline & & A 54 & C. coli & C. coli & $\mathrm{a}$ \\
\hline & & A 55 & C. coli & C. coli & $\mathrm{a}$ \\
\hline & & A 56 & C. coli & C. coli & $\mathrm{a}$ \\
\hline & & A 57 & C. coli & C. coli & $\mathrm{a}$ \\
\hline & & A 58 & C. jejuni & C. jejuni & $\mathrm{b}$ \\
\hline \multirow[t]{3}{*}{ Slaughterhouse B } & Carcass swab & B6 & C. lari & $\varnothing$ & / \\
\hline & \multirow[t]{2}{*}{ Neck skin } & B13 & C. jejuni & C. jejuni & c \\
\hline & & B15_ & C. jejuni & C. jejuni & d \\
\hline \multirow[t]{10}{*}{ Slaughterhouse C } & \multirow[t]{10}{*}{ Carcass swab } & $\mathrm{C} 23$ & C. coli & C. coli & e \\
\hline & & $\mathrm{C} 24$ & C. coli & C. coli & e \\
\hline & & $\mathrm{C} 25$ & C. coli & C. coli & e \\
\hline & & $\mathrm{C} 26$ & C. coli & C. coli & e \\
\hline & & C34 & C. coli & C. jejuni & $\mathrm{f}$ \\
\hline & & C35 & C. coli & C. јејипi & g \\
\hline & & C36 & C. coli & C. jejuni & $\mathrm{h}$ \\
\hline & & C38 & C. coli & C. jejuni & $\mathrm{i}$ \\
\hline & & C59 & C. jejuni & C. jejuni & $\mathrm{b}$ \\
\hline & & $\mathrm{C} 60_{-}$ & C. jejuni & C. jejuni & j \\
\hline Slaughterhouse W & Carcass swab & W52 & C. coli & C. jejuni & $\mathrm{k}$ \\
\hline \multirow{2}{*}{$\begin{array}{l}\text { Public Health Institute } \\
\text { V }\end{array}$} & \multirow[t]{2}{*}{ Human feces } & V16 & C. coli & C. jejuni & 1 \\
\hline & & V17 & C. coli & C. coli & $\mathrm{m}$ \\
\hline \multirow[t]{3}{*}{ Farm P } & \multirow[t]{3}{*}{ Caecum } & P27 & C. coli & C. coli & $\mathrm{n}$ \\
\hline & & P29 & C. coli & C. coli & $\mathrm{n}$ \\
\hline & & P30 & C. coli & C. coli & $\mathrm{n}$ \\
\hline
\end{tabular}

All of the 30 isolates of Campylobacter were analyzed by primers for mapA and ceuE genes [14]. Amplicons of different size specific for C. jejuni and C. coli (589 bp and 462 bp, respectively) were obtained (Fig. $1 \mathrm{a}$ and $1 \mathrm{~b}$ ). Summary of the results revealed 13 isolates of C.jejuni, and 15 isolates of C. coli. One of the isolates yielded both products (A53) and one did not give any amplification (B6). 
Results obtained by m-PCR slightly differed from biochemical testing. Sample A2 was characterized as $C$. jejuni by biochemical tests and as C. coli by m-PCR. Samples C34, C35, C36 and C38, characterized as $C$. coli by biochemical tests were characterized as C. jejuni by m-PCR. Sample A53 produced both bands specific for C. jejuni and C. coli. Test was repeated three times and the results were identical.

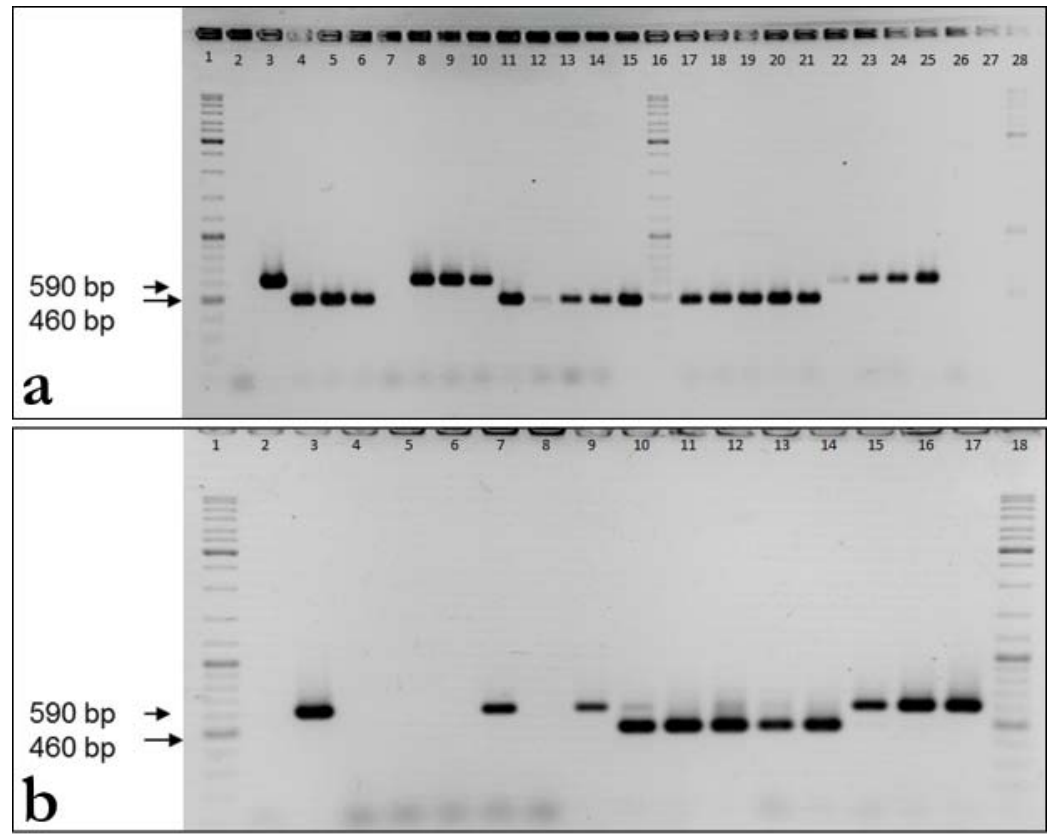

Figure 1. m-PCR of C. jejuni i C. coli isolates based on mapA and ceuE genes. a) Lanes 1, 16 and 28. M - GeneRuler DNA Ladder Mix SM0331 (ThermoScientific, Lithuania); Lanes 2, 26 and 27. blank; Lane 3. C. jejuni ATCC strain R51; Lanes 4-15. Isolates: A1; A2; A4; B6; B13; B15; V16; V17; Z20; Z21; C23; C24; Lanes 17-27. Isolates: C25; C26; P27; P29; P30; C34; C35; C36; C38; b) Lanes 1 and 18. M - GeneRuler DNA Ladder Mix SM0331 (ThermoScientific, Lithuania); Lanes 2, 4, 5 and 6. blank; Lane 3. C. jejuni ATCC strain R51; Lanes 7-17. Isolates: A43; A46; W52; A53; A54; A55; A56; A57; A58; C59; C60

\section{RAPD analysis}

RAPD was performed with 10 primers. Some of those primers were formerly used for Campylobacter testing, e.g. OPA8 and OPA10, while others were used with different bacterial genomes or for plant genome analysis. One primer was designed for this study and named DJP17. Results obtained with primer SPH1 were less informative. Primers BC318, AF14, AK16 (data not shown) and OPA8 could not differentiate isolates within the species, but could distinguish C. jejuni from C. coli. Primers OPA10 and AX16 did not produce any amplification with the investigated isolates under recommended conditions. Discriminatory potential of the primer DJP17 specifically designed for this study has been tested and obtained patterns contained 3 to 10 different product sizes (Fig. 2). 


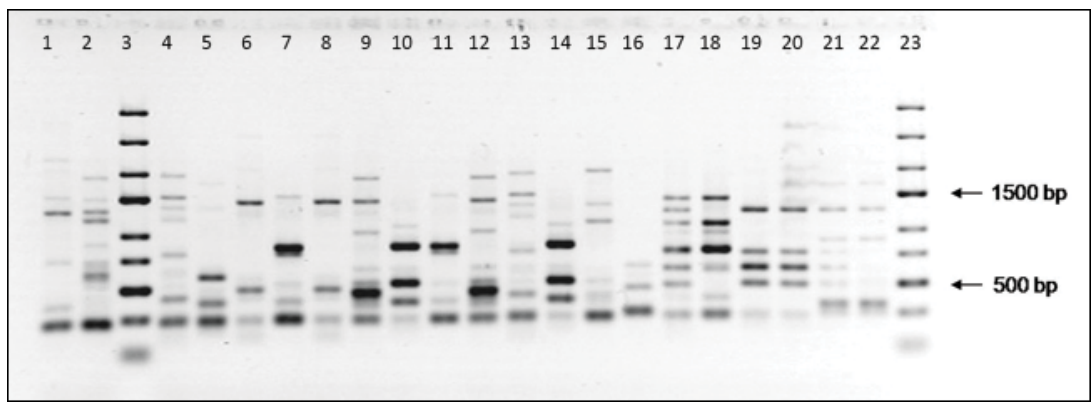

Figure 2. Representative RAPD patterns of C. jejuni and C. coli isolates according to DJP17 primer. Lanes 1 and 2. C. jejuni ATCC strains: R50, R51; Lanes 3 and 23. M- GeneRuler Express DNA Ladder SM1551 (ThermoScientific, Lithuania); Lanes 4-15. C. jejuni isolates: A43; A58; B13; B15; W52; C34; C35; C36; C38; C59; C60; V16; Lane 16. A53; Lanes 17-22. C. coli isolates: P29; V17; A1; A2; C25; C26.

Primers AP10, AG15 and DJP17 produced profiles with multiple product size and enabled typing of all the isolates (Fig. 3). Cumulative RAPD analysis was performed according to results obtained with primers OPA8, SPH1, AG15, AP10 and DJP17 and 14 different patterns were obtained: 10 for $C$. jejuni and 4 for $C$. coli (Table 1). C. jejuni isolates are clearly distinguished from $C$. coli isolates forming separate clusters. $C$. jejuni cluster shows significant differences on the isolate level, while differences among $C$. coli isolates are not very expressed (around 18\%).

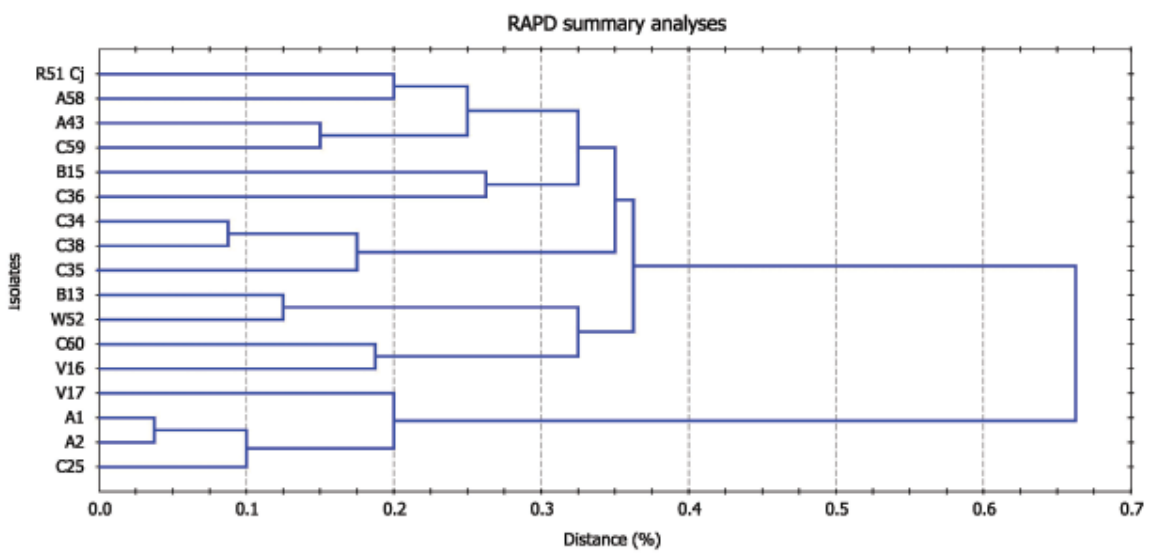

Figure 3. Cumulative RAPD analysis of representative $C$. jejuni and $C$. coli isolates using primers OPA8, SPH1, AG15, AP10 and DJP17.

\section{DISCUSSION}

The purpose of this study was to investigate diversity of C. jejuni strains present in the Republic of Serbia and to determine a fast and reliable system for the confirmation of 
the isolated strains. As it is sometimes difficult to identify isolates to the species level, the combination of biochemical tests and $\mathrm{m}$-PCR provides an excellent solution to this problem. Comparison of biochemical tests results and $\mathrm{m}-\mathrm{PCR}$ reveals few differences: there were some isolates negative on hippurate hydrolysis test which were classified as C. jejuni by m-PCR, as well as one isolate which was hippuricase-positive, but identified as $C$. coli in $\mathrm{m}$-PCR. These results are similar to the results obtained by Al Amri et al. [21] who also obtained false negative results - isolates were hippuricase-negative, but belonged to $C$. jejuni species and false positive results - isolates were hippurate positive, but m-PCR aligns them into $C$. coli. Authors concluded that possible explanation of this finding is that $C$. coli possess an enzyme whose substrate is similar to hippurate, so it disassembles it creating a false positive reaction and false negatives are present when hippuricase gene is not active in the isolate [22,23].

One of the tested isolates yielded amplicons with both sets of primers in m-PCR (isolate A53). In consecutive investigation with RAPD primers it behaved as C. jejuni (primers AG15, OPA8) or C. coli (primers SPH1, AP10). This finding indicates a mixed infection in broilers. The cases of mixed cultures in the flock or herd were already documented. Al Amri et al. [21] detected mixed infection in feces of broilers and humans. Boes et al. [24] investigated the presence of C. jejuni and C. coli in pig herds on strictly pig farms and mixed farms (pigs / poultry, pigs / cattle). The incidence of C. coli was higher than $90 \%$ regardless of farm type (strictly pigs or mixed). In mixed farms C. jejuni predominated in cattle and poultry and C. coli in pigs, but there were evidence of mixed infection in pigs $-C$. jejuni positive pigs often excreted $C$. coli as well.

RAPD investigation described in this article was conducted in three steps. The first step included primes that were already used by other investigators (OPA8, OPA10) and gave discriminative results for Campylobacter [17]. We could not repeat these results - primer OPA10 did not produce and OPA8 produced poor amplicons under recommended conditions. Primer OPA8 detects minor differences among $C$. jejuni isolates, and all $C$. coli isolates produce the same profile. In the second step the following primers (SPH1, AP10, AK16, AG15) were used for RAPD typing. Primer DJP17 was synthesized for the third step of this investigation.

Cluster analysis of cumulative RAPD clearly separated C. jejuni from C. coli; clusters were mutually different $56 \%$. C. coli isolates were mutually similar, they differ maximally $20 \%$. Poultry isolates were highly similar (90\%), while human isolate V17 was $20 \%$ different from isolates originating from poultry. These findings suggest that poultry was not the source of $C$. coli infection for humans, but extensive investigation is needed. C. jejuni cluster consisted of 2 subclusters. Isolates C34, C35, C36 and C38, belonging to the first subcluster, originated from the same sampling in one slaughterhouse. They were characterized as $C$. coli by biochemical tests and as $C$. jejuni by m-PCR. RAPD analysis confirmed m-PCR findings separating these isolates into distinct cluster of C. jejuni isolates and clarified biochemical test results. C. jejuni isolates A43 and C59 originating from different sampling cluster together in the second subcluster. 
We obtained 14 different RAPD patterns, 10 for $C$. jejuni and 4 for $C$. coli. Isolates with distinctive origin were clustered together in the single and cumulative RAPD analysis, while isolates obtained in the same sampling were divided into different clusters, subclusters or branches. These results suggested that RAPD can be used as a typing tool in epidemiological investigations to clarify the sources of infection and way of transmission. RAPD analysis is already used in Campylobacter studies. Açik and Çetinkaya [12] used this method in the characterization of C. jejuni and C. coli isolated from healthy cattle and sheep. They used primer OPA11 and obtained 37 profiles of C. jejuni and 5 profiles of $C$. coli in cattle compared to 21 C. jejuni and 24 C. coli profiles in sheep. RAPD have been used in the genetic variability analysis of $C$. jejuni and $C$. coli from commercial broiler farms in Italy [25]. Giacomelli and associates used RAPD primer AP4 for characterization of isolates obtained from cloacal swabs. They obtained 11 different RAPD patterns, 8 for $C$. jejuni and 3 for $C$. coli isolates.

Campylobacter characterization by RAPD can be useful in the case of a mixed infection with bacteria from other genera. In Serbia, the influence of Salmonella enterica infection in chickens on the outcome of campylobacteriosis in experimental conditions has been investigated on the basis of morphological, cultural and biochemical properties [26]. The field strain of C. jejuni used in their study may be compared with isolates from our study by RAPD analysis using primers selected in this work.

Primer DJP17, used for diversity screening of C. jejuni in Serbia for the first time, was very informative in distinguishing indigenous $C$. jejuni and can help connecting them to the potential source of infection. Before recommending DJP17 for wider use it is necessary to expand the research and apply this primer to a larger number of isolates from Serbia and abroad.

\section{Acknowledgments:}

The work was partially supported by the Ministry of Education, Science and Technological Development of the Republic of Serbia (Projects Numbers: III 46007 and III 46009).

\section{Authors' contributions}

DJ carried out the molecular genetic studies, participated in the sequence alignment, participated in the design of the study and performed the statistical analysis and conceived of the study, drafted the manuscript and coordination to draft the manuscript. JP conceived of the study, performed the statistical analysis and participated the design of the study and coordination and helped to draft the manuscript. OB, ZL, RP, ZR, VK conceived of the study, and participated in its design and coordination and helped to draft the manuscript. All authors read and approved the final manuscript. 


\section{Declaration of conflicting interests}

The author(s) declared no potential conflicts of interest with respect to the research, authorship, and/or publication of this article.

\section{REFERENCES}

1. Blaser MJ: Epidemiologic and clinical features of Campylobacter jejuni infections. J Infec Dis 1997, 176:103-105.

2. Altekruse SF, Stern NJ, Fields PI, Swerdlow DL: Campylobacter jejuni - An emerging foodborne pathogen. Emerg Infect Dis 1999, 5:28-35.

3. Tauxe RV Emerging food borne pathogens. Intern J Food Microbiol 2002, 78: 31-41.

4. European Food Safety Authority: Scientific Opinion on Campylobacter in broiler meat production: control options and performance objectives and/or targets at different stages of the food chain. EFSA Journal 2011, 9:1-141.

5. Scallan E, Hoekstra RM, Angulo FJ, Tauxe RV, Widdowson MA, Roy SL, Jones JL, Griffin PM: Foodborne Illness Acquired in the United States-Major Pathogens. Emerg Infect Dis 2011, 17:7-15.

6. Devane ML, Nicol C, Ball A, Klena JD, Scholes P, Hudson JA, Baker MG, Gilpin BJ, Garrett N, Savil MG: The occurrence of Campylobacter subtypes in environmental reservoirs and potential transmission routes. J Appl Microbiol 2005, 98:980-990.

7. Stanley K, Jones K: Cattle and sheep farms as reservoirs of Campylobacter. J Appl Microbiol 2003, 94:104S-113S.

8. OIE Terestrial manual: Campylobacter jejuni and Campylobacter coli. 2008

9. Achen M, Morishita TY, Ley EC: Shedding and colonisation of Campylobacter jejuni in broilers from day-of-hatch to slaughter age. Avian Dis 1998, 42:732-737.

10. Engberg J, Aarestrup FM, Taylor DE, Gerner-Smidt P, Nachamkin I: Quinolone and macrolide resistance in Campylobacter jejuni and Campylobacter coli: resistence mechanisms and trends in human isolates. Emerg Infect Dis 2001, 7:24-34.

11. Nadeau R, Messier S, Quessy S: Prevalence and comparison of genetic profiles of Campylobacter strains isolated from poultry and sporadic cases of campylobacteriosis in humans. J Food Prot 2002, 65:73-78.

12. Açik MN, Çetinkaya B: Random amplified polymorphic DNA analysis of Campylobacter jejuni and Campylobacter coli isolated from healthy cattle and sheep. J Med Microbiol 2006, 55:331-334.

13. Behringer M, Miller WG, Oyarzabal O: Typing of Campylobacter jejuni and Campylobacter coli isolated from live broilers and retail broiler meat by flaA-RFLP, MLST, PFGE and REP-PCR. J Microbiol Meth 2011, 84:194-201.

14. Denis M, Soumet C, Rivoal K, Ermel G, Blivet D, Salvat G, Colin P: Development of a m-PCR assay for simultaneous identification of Campylobacter jejuni and Campylobacter coli. Lett Appl Microbiol 1999, 29:406-410.

15. Møller Nielsen E, Engberg J, Fussing V, Petersen L, Brogren CH, On SLW: Evaluation of phenotypic and genotypic methods for subtyping of Campylobacter jejuni isolates from human, poultry and cattle. J Clin Microbiol 2000, 38:3800-3810. 
16. Trajkovska-Dokić E, Stojkovska S, Icev K, Grozdanova A: Serogrouping and randomly amplified polimorphic DNA fingerprinting of Campylobacter jejuni. Maced J Med Sci 2011, 4:372-375.

17. Tan YF, Haresh KK, Chai LC, Son R: Antibiotic susceptibility and genotyping by RAPD of Campylobacter jejuni isolated from retailed ready-to-eat sushi. Internat Food Res J 2009, 16:31-38.

18. Mliki A, Staub AE, Zhangyong S, Ghorbel A: Genetic diversity in melon (Cucumis melo L.): Anevaluation of African germplasm. Gen Res Crop Evol 2001, 48:587-597.

19. Dooley JJ, Harrison SP, Mytton LR, Dye M, Cresswell A, Skot L, Beeching JR: Phylogenetic grouping and identification of Rhizobium isolates on the basis of random amplified polomorphic DNA profiles. Can J Microbiol 1993, 39:665-673.

20. Selenska-Pobell S, Evguenieva-Hackenberg E, Radeva G, Squartini A: Characterization of Rhizobium hedusari by RFLP analysis of PCR amplified rDNA and by genomic fingerprinting. J Appl Bacteriol 1996, 80:517-528.

21. Al Amri A, Senok AC, Ismaeel AY, Al-Mahmeed AE, Botta GA: Multiplex PCR for direct identification of Campylobacter spp. in human and chicken stools. J Med Microbiol 2007, 56:1350-1355.

22. Linton D, Lawson AJ, Owen RJ, Stanley J: PCR Detection, Identification to Species Level, and Fingerprinting of Campylobacter jejuni and Campylobacter coli Direct from Diarrheic Samples. J Clin Microbiol 1997, 35:2568-2572.

23. Sinha S, Prasad KN, Pradhan S, Jain D, Jha S: Detection of preceding Campylobacter jejuni infection by polymerase chain reaction in patients with Guillain-Barre syndrome. Trans $\mathrm{R}$ Soc Trop Med Hyg 2004, 98:342-346.

24. Boes J, Nersting L, Nielsen EM, Kranker S, Enøe C, Wachmann HC, Baggesen DL: Prevalence and diversity of Campylobacter jejuni in pig herds on farms with and without cattle or poultry. J Food Prot 2005, 68:722-727.

25. Giacomelli M, Andrighetto C, Rossi F, Lombardi A, Rizzotti L, Martini M, Piccirillo A: Molecular characterization and genotypic antimicrobial resistance analysis of Campylobacter jejuni and Campylobacter coli isolated from broiler flocks in northern Italy. Avian Pathol 2012, 41:579-588.

26. Stojanov I, Stojanović D, Milić N, Živkov Baloš M, Kapetanov M, Ašanin N, Čogurić I: Influence of salmonella infection in chickens on the outcome of campylobacteriosis in experimental conditions. Acta Veterinaria 2011, 61:157-65.

\title{
TIPIZACIJA IZOLATA CAMPYLOBACTER SPP POREKLOM IZ REPUBLIKE SRBIJE PRIMENOM M-PCR I RAPD METODA
}

\author{
JOŠIĆ Dragana, PETKOVIĆ Jelena, BUNČIĆ Olivera, LEPŠANOVIĆ Zorica, \\ PIVIĆ Radmila, RAŠIĆ Zoran, KATIĆ Vera
}

Kampilobakterioza je infektivna bolest ljudi izazvana termofilnim bakterijama roda Campylobacter, uglavnom vrstama C. coli i C. jejuni. Jedan je od vodećih uzroka gastroenteritisa, pri čemu broj obolelih premašuje broj infekcija Salmonella vrstama. Epi- 
demiologija uzročnika nije u potpunosti rasvetljena, ali je u mnogim istraživanjima naglašena uloga pilećeg mesa u infekciji ljudi. Cilj ovog istraživanja bio je ispitivanje diverziteta Campylobacter vrsta prisutnih u Republici Srbiji i uspostavljanje brzog i pouzdanog sistema za potvrdu i tipizaciju dobijenih izolata. Ispitivani su uzorci uzeti sa farmi brojlera i iz klanica živine, kao i 2 izolata poreklom od ljudi. Identifikacija izolata vršena je primenom multiplex-PCR-a. Genotipizacija je vršena primenom analize nasumično umnožene polimorfne DNA (RAPD) sa više prajmera. Primenom prajmera neuobičajenih za ispitivanje Campylobacter vrsta i jednog novodizajniranog (DJP17), dobijeni su RAPD profili autohtonih Campylobacter izolata. Stepen diskriminacije izolata zavisio je od primenjenih prajmera: prajmeri SPH1 i AG15 bili su delimično informativni, dok su prajmeri AP10, AK16 i DJP17 dali bolje rezultate. 